\title{
The Importance of Communication, Cooperation of the Leader in the Process of Leadership in Education
}

\author{
MSc, Marigonë Krypa \\ European University of Tirana, Albania
}

\begin{abstract}
Communication is a complex process and an important element of human activity. Communication is an act of transfering data and information from one person to another person and also a skill that is learned through life. By different authors there are different definitions and descriptions of the communication process. Presented in this paper is the importance of the communication process leader during leadership, effective communication factors, ineffective and communication. Leader during the leadership uses different ways of communication are covered: Interviews, communication with two or more people, meetings, meetings, masiv- media communication, public communication, etc. Organizing meetings during the show director community must correctly, be prepared and be a good example for others.
\end{abstract}

Keywords: Leader, communication, efectiv, skills, good organization, information

\section{Introduction}

The art of communication and speech is a born master of unique and strong weapon which distinguishes a leader from another. Effective communication is an important part of the culture of communication, it is the basic tool for determining the trust and relationships with others, where its positive impact depends on how we are able to use, or to transmit the information to others. It's clearly expressing an opinion in speech or in writing is a factor which eliminates the communication problems. Misunderstandings are some of the problems that often occur in the process of leadership to the leaders, so great care should be taken in this regard.

A director of an institution or can not achieve anything only if it does not cooperate with the manager or other employees and, if action has not the support of other people, this is an issue very hard that the share of management and leadership. The report is a replacement director of the school with the teachers, relationships, communication and collaboration are key to the efficient functioning of the school. Communication and its mode of use with others is a tool for creating strong relationships that enable proper cooperation and support from other schools. Creating new connections with institutions and the establishment of collaborations is part of the success of the work. Organize good time director, organizing meetings, activities, meeting with people, communication mode of communication, and relationship management activities and meetings are important for the functioning of the school.

\section{Communication}

Communication is a key elementin any human activity. Communication is a learned skill.

However, while most people are born with the physical ability to talk, not all can communicate well unless they make special efforts to develop and refine this communication skill (Juliana, 2016:2).

Communication is a word derived from the Latin word communis or commūnicāre, which means 'to make common' or 'to share'. Communication is the act of conveying intended meaning to another person through the use of mutually understood signs and language (Juliana, 2016:2).

The process of speech and means of communication is a special quality of school leaders. One of the unique basic features which distinguishes man from other living beings is the ability of the communication process, the expression of feelings, emotions, thoughts, etc. 
Usually when we want a leader to guide us in the work we want to choose the person who has good skills of leadership is motivational, also one person that can be communicative and could have a good language communication which he use.

Some people seem to be born with a natural energy and confidence. Others must work at it. For all of us, the qualities of those who lead and succeed can be learned and strengthened. All it takes is a conscious effort to learn and apply personal communication skills on a consistent basis ëith the help of some honest feedback (Decker:7). Also, Bernard Baruch sayed that "The ability to express an idea is well nigh as important as the idea itself".

There are various descriptions and definitions for the communication process. Communication is a tool which makes information transfer from the donor to the recipient provided that makers to understand that, while the organization or institution is a means of communication that connects people to the realization of a common goal.

Effective communication is heavily dependent on effective listening, something many of us may not be fully proficient at. An additional purpose of effective listening is to convey interest and respect for the other person (Dixon:11).

"Communication is defined as the process by which ideas, information, opinions, attitudes and feelings are carried from one person to another. Human communication is the process of understanding between two or more people. What makes human communication unique is its superior ability to create and use symbols, because this is the skill that enables you to share the experience people (Morina, 2012: 7). "

Communication is the process by which information, knowledge and understanding are transferred from one person to another person, and a good opportunity to express attitude, opinion. Pleasures and discontent on a particular issue. A leader, a leader or manager of an institution most of the time spends communicating.

Communication between supervisors and staff is essential or many levels, from the top down, laterally or from the bottom up. Communication can effectively increase morale in the workplace but it can also increase dissention and worker dissatisfaction (Duncan, 2009:1).

According to the authors Scheiring and Mattheis at al, in research conducted in the education sector, they describe that communication is multi-dimensional, it is extremely important for the welfare of the school and practiced by all stakeholders in the school. The school director presents the model for effective communication (Scheiring, 2012: 9).

Communication is perhaps the most important part of the school, because if fighting all groups of stakeholders in a school are well informed and know how to communicate with each other, they are all the more motivated to achieve quality in school and working together in so intëenzive in various fields (Mattheis, et al., 2012: 6). Communication is a priority which impacts positively on the management of a school or institution and a tool which creates the opportunity to increase the quality of work by the school. The best option school director tells a confident, effective and lasting respect from others, he should use a regular communication with teachers, parents, school leaders. The key to solving any problem, within and outside the school is good communication. Good communication by the school principal means cooperation, information, being involved and respect for ideas or suggestions from others about a particular activity. According to the authors Scheiring, $\mathrm{H}$., Mattheis, C., et al, and research carried out in the education sector, they describe the causes of effective and ineffective communication (Mattheis \& al, 2012: 10):

\begin{tabular}{|l|l|}
\hline \multicolumn{2}{|l|}{ Effective communication versus bad communication } \\
\hline What disrupts communication & What helps communication \\
\hline • Have attitude - "I know!" & -Look instead to tell \\
- Not Listening & - Listen actively \\
- Being judgmental & - Push trial \\
- Focus on 'who' rather than the 'what' & - Focus on 'what,' stand on the issue! \\
- Blaming & - Troubleshooting - appropriate allocation of responsibilities for \\
- Standing behind a single personal agenda & action \\
- Misrepresentation or withholding information & - Understand your interests and those of others and seek \\
- Being argumentative & common ground \\
- Being justifying & - Share information \\
\hline
\end{tabular}

Table 1. Poor communication towards effective communication (Mattheis \& al, 2012:10) 
The table presented above on the causes of effective and ineffective communication that are due to bad communication towards effective communication along with factors that disrupt communication and factors that help the communication process.

Since communication is a process of exchange of information that takes place every day and he is considered to be the art of the success of a school principal, through speech director of transmitting information, knowledge, experiences, opportunities to teachers, students, staff working or to others. Its communication during working hours with others represents success in career and professional level, because it does not matter how long talks like the director of a school but "what speaks". According to some studies indicated that women speak more leaders than male leaders, while some other authors show otherwise, but as long as there are characters, traits and personalities of different women and men can not judge in this case.

By Paul Waltzawick people can not communicate and the ability to formulate and transmit thoughts in verbal terms is mandatory for the human being. For the dog a successful and effective communication by the director of the school, the process of transmission of information must be:

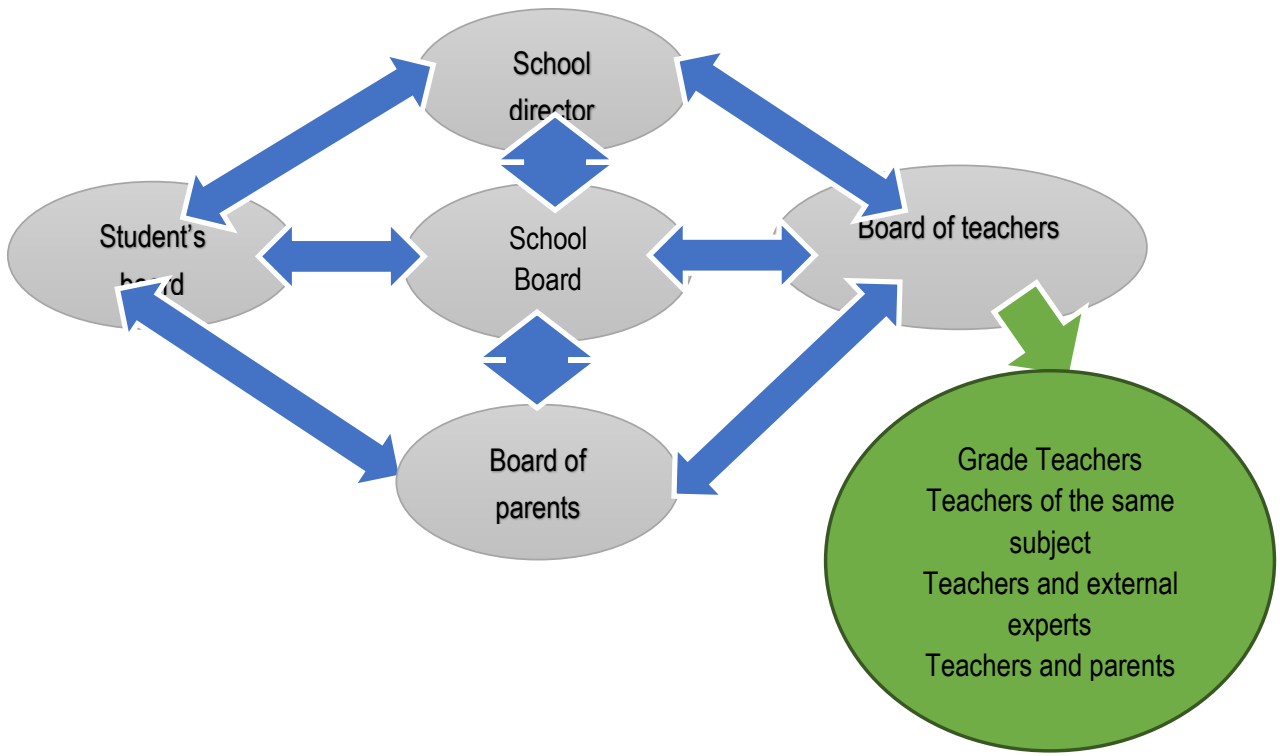

Figure. 1 method of communication within the school (Mattheis \& al, 2012, p. 7)

The chart below attempts to show different groups and structures of communication between them, for example, teachers should regularly communicate internally about teaching, learning, students, projects, etc. (Mattheis \& al, 2012, p. 7)

\section{Forms of Communication}

The author Bert Decker describes that vocal delivery and the visual elements, as ëell as personality, likeability, and openness are the primary ingredients of high-level interpersonal communications. But ëhat specific behavioral characteristics and traits make up these important ingredients and behavioral skills are (Decker:13):

Eye Communication

Posture and Movement

Gestures and Facial Expressions

Dress and Appearance

Voice and Vocal Variety

Language, Nonëords, and Pauses

Listener Involvement

Humor 
The Natural Self

Director of communications process with others may be in various forms and ways such as: interviews, communicating with two or more people, meetings, meetings, masiv- media communication, public communication, etc.

\section{Interviews}

During the working career as director of the school will definitely ket numerous occasions the interview by different persons, research, student, students, teachers, etc., on various issues about the profession, how to manage the school, successes and achievements It is shown in leadership activities or other professional topics. Director must always be ready to give correct answers, the cautions, provide accurate information, etc.

The interview is a process of communication that takes place between two persoanve called interviewer and interviewee. in this case the interviewer is the person who asks questions and the interviewee is the director of the school.

According to the authors Morina and develop interview Asllani with higher mental processes. Through mergers and sharing of information in the interview situation or by participation in various interviews, we gain insight into the decision making and problem solving as well as the growth of our intellectual capacity (Morina, 2012:20).

\section{Meetings and appointments}

Meetings and appointments organized by the director to be more successful and effective, they must first be well planned and teachers need to be informed on the topic that will be discussed at meeting. The author David E. Hartl sayed that "Meetings are a primary process for organizational life". Meetings are a form of organizing a group of people on getting any vention, discussing an issue, problem, planning. The meetings are part of the daily work of the director, which are organized within the school in order to discuss an event which has occurred or about what might happen in certain circumstances. Any decision taken by the school director should be based on facts and data, to be convincingly sober and reasonable.

"Meetings can often be" cabinet "of professionalism of employees and assist in career development, because employees better understand the nature of colleagues. Office meetings are not fun, but you should take part in them and to display more professionalism and respectful behavior to your colleagues " (Different authors, 2015). Usually held meetings with teachers several times during the first semester and second, depending on the cases and problems that occur in school. The meetings are organized at the beginning of the school year with teachers always have to present ourselves as a director before the session starts and should continue with presentations by the Deputy Director, the teachers new if there and then have begun to point mentioned, problems that must reviewed during the meeting.

Before the session starts a very important feature which characterizes the accuracy, reliability and professionalism of the director is that meetings are set schedule and you do not waste time to others. Coating which keeps the director before entering the meeting should jet in accordance with the code of professional ethics, in order to show credibility in front of others. Another feature of the gold and very important which makes the director to tell a good impression at the meeting is the way of speech, expression of opinions and the appropriate use of intonation of the voice in order to be sufficient and clear all teachers who are participating in the meeting. Also before the session starts director should be prepared what will be discussed at the meeting, create an agenda with the main points or topics that will be discussed, choose the manner or method appropriate moderation and also is very important to know to ask questions about the topic that has been discussed. It should also be provided and the fact that the director of the school should be able to answer questions or uncertainties that may have teachers during the discussion at the meeting. During the meeting, the Director should express his opinion about the extent information is required and you must involve all participants in the discussion, because meetings are not effective monologue. Usually it is not polite to interrupt others if they speak, but as the case may happen to be required to terminate any of the conversations of the participants in the meeting.

Depending on the topic, case, issue or problem to be treated for the duration of the meetings can be short or long. If meetings are long, preferably served something to drink in a meeting to be more entertaining for the participants because the place irrespective of time than would stay minutes will pass quickly, and at the same time leave the monotony of staying passive on the chair. In private schools in Kosovo during the meetings organized by the school with teaching participants usually served: tea, coffee, fruit juice, etc. 
Meetings as a form of organization of work by the school also have weaknesses in the planning or the organization of the meeting and has many advantages and benefits of these meetings.

\begin{tabular}{|l|l|}
\hline \multicolumn{2}{|l|}{ Strengths and weaknesses of meetings } \\
\hline Advantages / benefits of meetings & Weaknesses of meetings \\
\hline - Measurable progress, & - Sending invitations late, \\
- Planning of next steps, & - Invitations without time members, and points for discussion \\
- Assistance for communication, & (content) \\
- Exchange ideas, & - Use a room that is too small or too noisy, \\
- Exchange of pedagogical questions, & - If not seen the agenda before the meeting, \\
- Support for students or teachers, & - Meeting without purpose or agenda, \\
- Involvement of people in activities, & - Preparation weak or insufficient, \\
projects, processes & distribution of documents at the meeting, \\
- Learning from each other, & - chairmanship ineffective / lack of control, \\
• Develop the capacity working & - Discussion of irrelevant information, \\
each other, & - Moderation ineffective \\
- Encourage commitments and ideas & -'speech' as head by \\
action, & excluding other participants \\
- Support the skills to identify the best results, & - Failure of the meeting time, \\
- Mutual cooperation in conducting & - Non-implementation of the agenda, \\
actions. & - Failure to peer discussions in \\
& meeting, \\
& - The use of mobile phones in the meeting, \\
& - Lack of record keeping and its split with participants, etc. \\
\hline
\end{tabular}

Table 2. Strengths and weaknesses of meetings (Mattheis \& al, 2012:27)

In this table are presented meetings strengths and weaknesses facing the school principal together with the advantages I benefits of meetings and meetings weaknesses.

\section{Communication problems}

Some of the numerous problems faced by school directors are misunderstandings in communication with others. During communication, it is very important that school principals and send a clear message to accept. The message communicated by the school should be recognized as thought because something probably very small tone of voice as much as possible to transmit error message and cause misunderstanding of the purpose and meaning of the message. During communication with other school principal care must be taken:

- Have a clear purpose and opinion

- The chooses his words carefully when communicating

- The content is to be short and be understood

- Ensure that everyone should have received such information

\section{Levels of communication}

There are different types and ways of communication which can use a leading - the director of an educational institution such as: verbal and nonverbal communication, verbal, written, etc. Verbal communication is a communication process very important man and the golden key of a leader is a special quality and distinct innate in humans. This type of communication and transmission of messages encryption is done through words and speech. Verbal communication involves using speech to exchange information ëith others. We usually communicate verbally in face-to-face conversations such as; meetings, interviews, conferences, speeches, phone calls e. t. c. Much of the communication that takes place between people is both verbal and non-verbal; that is, it is based on language and gestures (Juliana, 2016:4).

Nonverbal communication - On the basis of that communication is carried with the use of any technical device which addresses a large number of people, this communication is directly related to mass communication and media. Such communication is not easy and is often referred to as "the language of communication of feelings" because during the presentation to the media except express opinions at the same time can express emotions, attitude, style attitude, tone of voice, orientation, etc. 
Communication is the transfer or forwards written- information and messages through the writing process. Messages can be sent through Viber, email or official letter, invitation or similar forms tjeravtë. The process of communication via email or other formve messaging, today is an indispensable part of the director's work. During the process of writing the email and sending it should be careful to show professionalism and sportsmanship, ways of writing is clear and easy to understand or easy to read should use an e professional who fits the position of the person who sent the email. Before you write a letter, as director of the school should always be careful in the way of writing, not ket errors script, use a professional greetings official and also as part of very important professional ethics is we are correct and return to answer all e-mails, calls, messages that we have received. How good working principle considered if we read an article some time before you send. For all meetings, communications, events, plans, qartësitë without qartësitë that occur during the day, etc. All these need to keep a notebook - block notes every day, except plans, formal concepts that keep on file.

\section{Formal non-verbal communication}

According to the decision of MEST Strategy developed communication in the education sector (Kasneci, 2011:8)

\begin{tabular}{l|l}
\hline Oral communication & Written communication \\
$\begin{array}{l}\text { Oral communication is more open to misunderstanding than that } \\
\text { in writing }\end{array}$ & $\begin{array}{l}\text { - Communication in writing is more efficient and effective to } \\
\text { ensure that all relevant stakeholders receive the same }\end{array}$ \\
$\begin{array}{ll}\text { - There is a preference for a style more } \\
\text { oral communication than personal }\end{array}$ & $\begin{array}{l}\text { message, and saves labor and time to contact people one by } \\
\text { on written communication }\end{array}$ \\
$\begin{array}{ll}\text { It can be traced. } & \text { Increases consistency and because communication is } \\
\text { documented and can be traced. }\end{array}$
\end{tabular}

\section{Cooperation}

Cooperation is a very important process and is the most powerful weapon of the success of a leader, business, organization, institution or country. In qof be that all staff within the school have a good cooperation between themselves and between them resulting in a positive working climate. Working in collaboration with school staff and school relationship with more partners from abroad is necessary and inevitable which also turns out to be the stimulating factor which influences the quality of the school. At school the opportunity to cooperate and communicate with various factors and external partner is quite large.

To realize a twinning with an institution, the school must develop a project which will be supported in developing a comprehensive strategy to ensure quality in the school. From such cooperation benefit students, teachers and schools. The school as an institution can establish cooperation with:

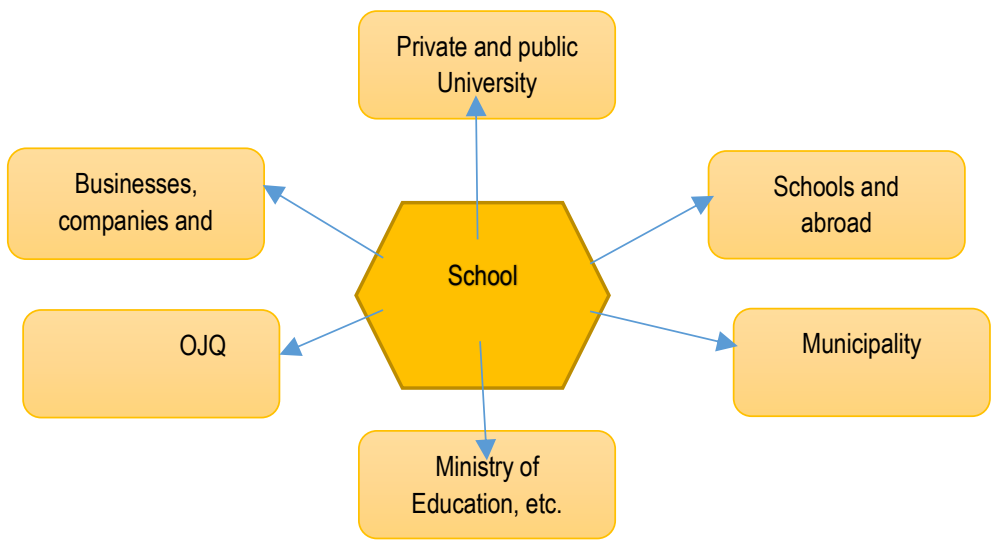

Figure. 2 collaborations between schools and external partners

Through this figure is presented the possibility of cooperation - cooperation between schools and external partners and stakeholders. 
School cooperation with different universities enables students an easier orientation in career towards their chosen profession. Through the cooperation of the school with other schools within or outside the country, they can exchange goods, activities or competitions in the various subjects, work experience, temporary visits of students and teachers, etc.

Through various NGOs inside and outside the country in which schools can establish cooperative links, school as an institution can have much better material benefits from the organization. For example:

Currently there are available these Non-Governmental Organizations: Beep, DAAD, GIZ, USAID Basic Education Program, I love Kosovo, Caritas, Terre des Homes (Swiss NGO), etc.

If it comes to a vocational school then it is good that schools let connections with as many businesses, hotels and organizations in order to enable students performing work practice and prepare their professional training. In secondary school student's internship takes longer than necessary and is completing the theory learned in school and as a positive result by the students is to link the theoretical with the practical.

Currently, Kosovo student practice this direction become makeshift classrooms in these schools, and students in a visit organized on their own businesses the most. The possibility that students perform best practice depends on the personnel working in these schools. (Shala, October 2015, p. 10)

For example, if a school in Kosovo's leadership "Hospitality and Tourism creates connections with a restaurant or hotel in a seaside location in Albania, it would be good for the students of the direction of practical work in coastal areas during holidays summer, so that students become more familiar with the products of the sea, their importance and preparation, hotel and restaurant management, tourism and requirements of tourists, etc.

School of Economics would be best to create as many links with various businesses in order to enable the creation of an effective system of professional practices that high school students to obtain practical skills by drejtimeve- different profiles.

A good cooperation: (Mattheis \& al, 2012, p. 12)

- The increased power to support teachers and students through teaching and learning,

- support the principal and school staff to achieve a higher quality school,

- creates opportunities for new teaching and learning, for example in practice firms and institutions,

- helps, for example, in financing and organizing excursions or development teaching and learning materials,

- creates a new kind of school culture and school profile,

- gives students the opportunity to learn more about their capabilities and They are planning their professional career,

- meets the requirements of the education legislation

\section{Conclusions}

A leader of the market, as crucial to success in leadership in his career he uses various forms of persuasive communication to express opinions to others, successes, problems, joys and grievances. Lidëerit care, fairness, respect his schedule and professional preparation before meetings makes it strong person, ambitious and serious work ethic. Always before using any form of communication we need to have a goal which we intend to achieve, if it comes to meeting or meetings we should draw attention to others through speech and to achieve the intended purpose. Sending messages, emails, formal letters, or invitations to others is a process that should be taken very carefully lest there be any mistake in writing the show as much professionalism, we have clarity in expressing thoughts and not use humor if missive. A leader who plans good things should never make promises you can not fulfill, because it can affect the loss of trust for others. Good communication is a key to solving the problems and is a unique qualities of a strong leader.

\section{References}

[1] Decker, B. (n. d. ). Communication skills for leaders, third edition. San Francisko: Axzo press.

[2] Dixon, T. O. (n. d. ). Communication skills. University of Ulster.

[3] DKA. (Janar 2012). Plani i punës një vjeçare, Drejtoria Komunale e Arsimit, viti shkollor 2011/2012, Nr. prot. 07-4/2012. Mitrovicë: Drejtoria Komunale e Arsimit. 
[4] Duncan, K. (2009). Leadership and Communication. Improving leadership and communication Skills for Municipal Managers and. Ontario.

[5] Hyseni, H., et al, Qeverisja dhe udhëheqja në arsim, 2003

[6] Juliana. (2016). Communication skills for undergraduates, Lecture notes. Amond University.

[7] Kasneci, M. A. (2011). Strategjia e komunikimit në sektorin e arsimit. Prishtinë: GIZ, MASHT Ministria e Arsimit Shkencës dhe Teknologjisw.

[8] Koleci, B. \& Reqica, F. Bazat e Menaxhmentit

[9] Mattheis, C., \& al, e. (2012). Komunikimi dhe bashkëpunimi: Zhvillimi i kapaciteteve në udhëheqjen arsimore. Prishtinë: GIZ.

[10] Mazreku, I., Bazat e menaxhimit, Prishtinë 2010

[11] Morina, D. A. (2012). Administrim biznesi. Prishtinë: Suat Berisha. ndryshëm, A. t. (2015, Gusht 13). si-tesilleni-ne-mbledhjet-e-zyres. Retrieved from sfidabiznesi: https://sfidabiznesi. com/si-te-silleni-ne-mbledhjet-ezyres/

[12] Pierce, M., Stapleton, D., Drejtori i shkollës i shekullit 21, 2011

[13] Ramosaj, B. (2007). Management. UP, botim i pestë. Prishtinë.

[14] Scheiring, H. M. (2012). Seminari Katër Komunikimi, Marrëdhëniet dhe Menaxhimi. Prishtinë: GIZ.

[15] Shala, D. (October 2015). Strategjia për rritjen e bashkëpunimit, gjithpërfshirjen dhe zhvillimin e shkollave të mesme profesionale dega Hotelieri-Turizëm në Komunat Pejë, Gjakovë dhe Prizren. Pejë: SEED.

[16] Zeqiri, I., Menaxhmenti, Tetovë, 2006 